\section{Exposures from radon, thoron, and thoron progeny in high background radiation area in Takandeang, Mamuju, Indonesia}

Miki Arian Saputra, Eka Djatnika Nugraha, Tri Purwanti, Rokhmat Arifianto, Roza Indra Laksmana, Richard P. Hutabarat, Masahiro Hosoda, Shinji Tokonami

\begin{abstract}
The exposure from radon, thoron, and thoron progeny was measured for 45 dwellings in high background radiation area in Takandeang, Indonesia with ambient dose equivalent rate ranging from $0.34 \mu \mathrm{Sv} \cdot \mathrm{h}^{-1}$ to $1.90 \mu \mathrm{Sv} \cdot \mathrm{h}^{-1}$. The measurement was taken using passive radon and thoron discriminative detector and thoron progeny detector. This measurement was taken from November 2018 to October 2019, and within one month the detector would be replaced with a new detector. The concentrations of radon, thoron, and thoron progeny were calculated as $42-490 \mathrm{~Bq} \cdot \mathrm{m}^{-3}, 20-618 \mathrm{~Bq} \cdot \mathrm{m}^{-3}$, and $4-40 \mathrm{~Bq} \cdot \mathrm{m}^{-3}$, respectively. The concentrations for out-

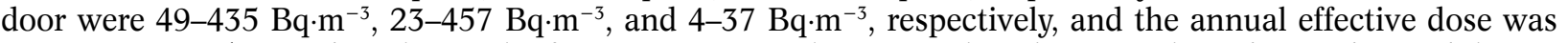
9.8-28.6 mSv $\cdot \mathrm{y}^{-1}$. Based on the result of Spearman's correlations analysis between the indoor radon and thoron concentrations and between the indoor thoron progeny and thoron concentrations, we suggest that exposure to thoron cannot be predicted from exposure to radon, and the equilibrium equivalent thoron concentration has a large uncertainty when it is estimated from thoron concentration assuming a single thoron equilibrium factor.
\end{abstract}

Keywords: CR-39 $\bullet$ High background radiation area $\bullet$ RADUET $\bullet$ Radon $\bullet$ Thoron $\bullet$ Thoron progeny

\section{A. Saputra}

Graduate School of Health Sciences, Hirosaki University 66-1 Honcho, Hirosaki, Aomori 036-8564, Japan and Center for Nuclear Minerals Technology - National Nuclear Energy Agency of Indonesia

Jl. Ps. Jumat, Lebak Bulus Raya No. 9, Cilandak, Jakarta, Selatan 12440, Indonesia

\section{E. D. Nugraha}

Center for Technology of Radiation Safety and Metrology National Nuclear Energy Agency of Indonesia Jl. Lebak Bulus Raya No. 49, Jakarta 12440, Indonesia

T. Purwanti, R. Arifianto, R. I. Laksmana, R. P. Hutabarat Center for Nuclear Minerals Technology - National Nuclear Energy Agency of Indonesia

Jl. Ps. Jumat, Lebak Bulus Raya No. 9, Cilandak, Jakarta, Selatan 12440, Indonesia

\section{Hosoda}

Graduate School of Health Sciences, Hirosaki University 66-1 Honcho, Hirosaki, Aomori 036-8564, Japan and Institute of Radiation Emergency Medicine Hirosaki University

66-1 Honcho, Hirosaki, Aomori 036-8564, Japan

\section{S. Tokonami ${ }^{凶}$}

Institute of Radiation Emergency Medicine

Hirosaki University

66-1 Honcho, Hirosaki, Aomori 036-8564, Japan

E-mail: tokonami@hirosaki-u.ac.jp

Received: 27 November 2019

Accepted: 28 January 2020

\section{Introduction}

Radon $\left({ }^{222} \mathrm{Rn}\right)$ and thoron $\left({ }^{220} \mathrm{Rn}\right)$ are produced in the ground by the decay of ${ }^{238} \mathrm{U}$ and ${ }^{232} \mathrm{Th}$ series, respectively. ${ }^{222} \mathrm{Rn}$ has a half-life of 3.8 days and ${ }^{220} \mathrm{Rn}$ has a half-life of $55.6 \mathrm{~s}$. Thoron is presented together with radon and both of them are referred to as radon concentration in the environment, while the amount of thoron is less than ${ }^{222} \mathrm{Rn}$ because of its half-life. Radon is known as the largest contributor to a background radiation dose measurement.

According to the National Council on Radiation Protection and Measurement (NCRP) report, more than $80 \%$ of radon and thoron that was released into the atmosphere are originated from topsoil and the remaining are originated from other sources. The concentration of radon in the atmosphere varies, depending on the place, time, and height above the ground, the meteorological condition, the topography, the house construction type, and even the lifestyle of the people [1]. Most of our time is spent within buildings; therefore, the measurement and limitation of radon concentration of buildings are important. The Environmental Protection Agency (EPA) estimates that 21000 lung cancer-related deaths in the United States every year are attributable to radon, and it is the leading environmental cause of cancer death in North America [2]. According to the EPA and the World Health Organization 

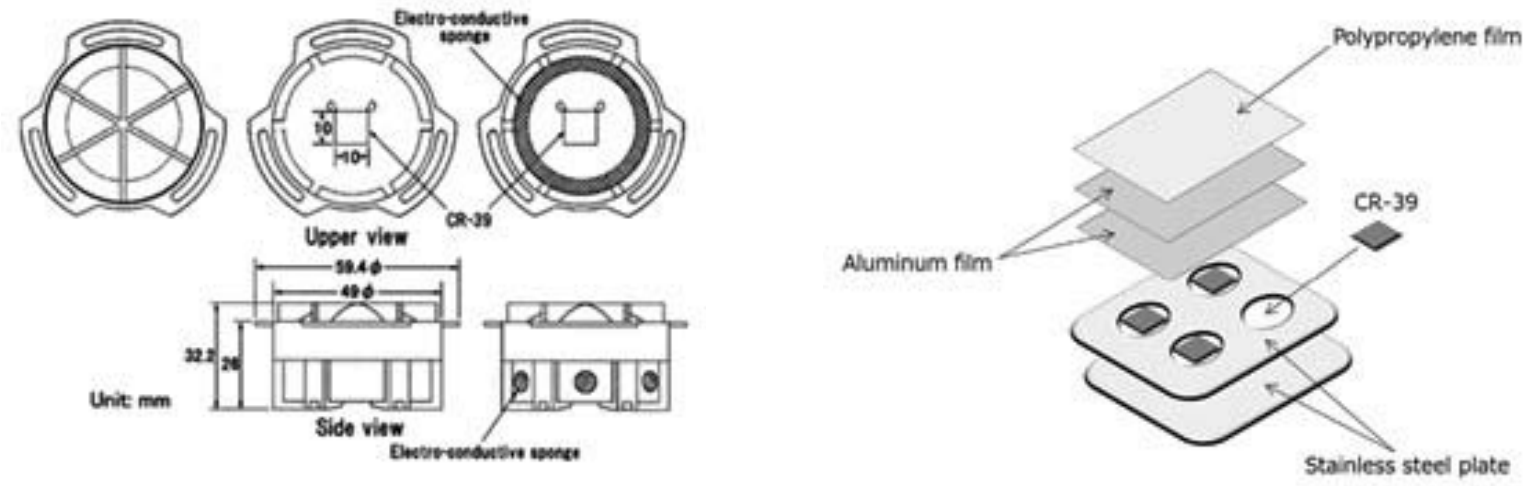

Fig. 1. RADUET (left) and thoron progeny detector (right) [6].

(WHO) Handbook on indoor radon, it is the second leading cause of lung cancer after smoking. The study aims to estimate the exposures from radon, thoron, and thoron progeny in high background areas in Takandeang, Mamuju, Indonesia.

\section{Materials and methods}

\section{Study area}

Mamuju has been known to have a high radiation dose rate around 13 times higher than normal, which comes from naturally occurring radioactive material (NORM) in rock and soil. It has been reported that the high radiation dose rate is due to its natural uranium content $\left({ }^{226} \mathrm{Ra}\right.$ and ${ }^{222} \mathrm{Rn}$ gases, both of which are highly water-soluble) [3]. The area under this study is in Takandeang village, Mamuju, Indonesia. Takandeang is one of the high background radiation areas in Indonesia. Takandeang has nine sub-villages, namely, Tabanga-banga, Bettengkatta, Rantai Dunia, Takandeang, Salubiru, Palada, Limbeng, Taloba, and Salumati.

Indonesia has only two seasons, the summer season is from April to September and the rainy season is from October to March. The climate of Takandeang is characterized by moderate temperature, summer season, and rainy season. During the summer season, the average temperature ranges from $29^{\circ} \mathrm{C}$ to $35^{\circ} \mathrm{C}$ with a rainfall of 10-50 mm.season ${ }^{-1}$, and during the rainy season, the average temperature is around $26^{\circ} \mathrm{C}$ to $29^{\circ} \mathrm{C}$ with a rainfall of $42-126 \mathrm{~mm} \cdot$ season $^{-1}$. The ambient dose in Takandeang is around 0.34-1.90 $\mu \mathrm{Sv} \cdot \mathrm{h}^{-1}$. The highest one is in the Palada area and the lowest one is in the Tabanga-banga area.

\section{Building materials}

Most of the houses in the Takandeang village are wood houses and partially ventilated, and only a few are concrete types with poor ventilation. The concrete houses are built using bricks, cement, and sand as the building materials. Each house has two to three rooms. Most of these houses have two windows and two doors.

\section{Detectors}

The radon and thoron concentrations were measured simultaneously using passive radon and thoron discriminative detector (RADUET) and thoron progeny detector. RADUET has two diffusion chambers (low and high diffusion chamber) with different air-exchange rates [4]. Each chamber contains a CR-39 chip of $10 \times 10 \mathrm{~mm}^{2}$ in size (Fig. 1). The CR-39 detector is fixed to detect the track of alpha particles. The low diffusion rate chamber is made of electro-conductive plastic with an inner volume of $30 \mathrm{~cm}^{3}$. The high diffusion chamber used for the measurement of both radon and thoron concentrations contains six holes of $6 \mathrm{~mm}$ diameter that are opened in the chamber sidewall and are covered with an electro-conductive sponge to prevent radon and thoron progeny from easily going into the chamber [4]. Thoron progeny measurement was carried out using a deposition rate detector. This detector consists of CR-39 chips that are covered with an aluminized Mylar film of $71 \mathrm{~mm}$ thickness (Fig. 1) in the air for the discrimination of high-energy alpha particles especially those emitted from ${ }^{212} \mathrm{Po}(8.78 \mathrm{MeV})$ [5].

A total of 45 dwellings were selected for measuring radon, thoron, and thoron progeny. A pair of detectors was suspended on the ceiling at a height of $1.5-2.0 \mathrm{~m}$ from the floor and $1 \mathrm{~m}$ from the wall indoor, whereas for outdoor the detector was suspended at 2.5-3.0 m far away from the houses at a height of $1.5-2.0 \mathrm{~m}$. The detector was put indoor and outdoor for one year, the detector was changed with a new one within one month, and the old one was sent to Hirosaki University to analyse the track.

\section{Activity concentrations calculation}

After exposure, the CR-39 chips were sent back to Hirosaki University to analyse the track. The CR-39 was etched in a $6 \mathrm{M} \mathrm{NaOH}$ solution at $60^{\circ} \mathrm{C}$ for $24 \mathrm{~h}$ [6]. After etching, the CR-39 was washed in distilled water properly and then dried up in temperature laboratory conditions. The tracks density was counted by the software Image J based on an image from an optical microscope. The obtained track densities were substituted into the following equations [7]: 


$$
\begin{gathered}
\bar{C}_{\mathrm{Rn}}=\left(d_{\mathrm{L}}-\bar{b}\right) \cdot \frac{f_{\mathrm{Tn} 2}}{t \cdot\left(f_{\mathrm{Rn} 1} \cdot f_{\mathrm{Tn} 2}-f_{\mathrm{Rn} 2} \cdot f_{\mathrm{Tn} 1}\right)}-\left(d_{\mathrm{H}}-\bar{b}\right) \\
\cdot \frac{f_{\mathrm{Tn} 1}}{t \cdot\left(f_{\mathrm{Rn} 1} \cdot f_{\mathrm{Tn} 2}-f_{\mathrm{Rn} 2} \cdot f_{\mathrm{Tn} 1}\right)} \\
\bar{C}_{\mathrm{Tn}}=\left(d_{\mathrm{H}}-\bar{b}\right) \cdot \frac{f_{\mathrm{Rn} 1}}{t \cdot\left(f_{\mathrm{Rn} 1} \cdot f_{\mathrm{Tn} 2}-f_{\mathrm{Rn} 2} \cdot f_{\mathrm{Tn} 1}\right)}-\left(d_{\mathrm{L}}-\bar{b}\right) \\
\cdot \frac{f_{\mathrm{Rn} 2}}{t \cdot\left(f_{\mathrm{Rn} 1} \cdot f_{\mathrm{Tn} 2}-f_{\mathrm{Rn} 2} \cdot f_{\mathrm{Tn} 1}\right)}
\end{gathered}
$$

where $d_{\mathrm{L}}$ and $d_{\mathrm{H}}$ are the alpha track densities [track $\cdot \mathrm{cm}^{-2}$ ] for the low and high air-exchange-rate chambers, respectively. $f_{\mathrm{Rn} 1}$ and $f_{\mathrm{Tn} 1}$ are the respective conversion factors from alpha track densities to radon and thoron activity concentrations for the low exchange-rate air chamber, with values 4.35 and 0.24 tracks. $\mathrm{cm}^{-2} \cdot\left(\mathrm{Bq} \cdot \mathrm{m}^{-3} \cdot \mathrm{h}\right)^{-1}$, respectively. $f_{\mathrm{Rn} 2}$ and $f_{\mathrm{Tn} 2}$ are the respective conversion factors from alpha track densities to radon and thoron activity concentrations for the high exchange-rate air chamber, with values 3.65 and 4.32 tracks $\cdot \mathrm{cm}^{-2} \cdot\left(\mathrm{Bq} \cdot \mathrm{m}^{-3} \cdot \mathrm{h}\right)^{-1}$, respectively. $t$ is the exposure time $[\mathrm{h}] . b$ is the background of the alpha track density [track $\cdot \mathrm{cm}^{-2}$ ] on the CR-39 detector. For calculating thoron progeny concentration (equilibrium equivalent thoron concentration (EETC)), the obtained track density was substituted into the following equation:

$$
N_{\mathrm{TnP}}=\mathrm{EETC} \cdot F_{\mathrm{TnP}} \cdot T+N_{\mathrm{B} 2}
$$

where $N_{\mathrm{TnP}}$ is the track density of CR-39 in the thoron progeny deposition detector, $N_{\mathrm{B} 2}$ is the background track density of CR-39 in the thoron progeny deposition detectors, $T$ the exposure time, and $F_{\mathrm{TnP}}$ is the conversion factor for the thoron progeny deposition detector. From the results of a field survey [5] and the chemical etching conditions, the value of $F_{\mathrm{TnP}}$ was $6.9 \times 10^{-2}$ tracks $\cdot \mathrm{cm}^{-2} \cdot\left(\mathrm{Bq} \cdot \mathrm{m}^{-3} \cdot \mathrm{h}\right)^{-1}$.

\section{Estimation of annual effective doses}

The indoor annual effective dose was evaluated in this study from activity concentrations of radon and thoron progenies. In addition, thoron concentrations were not taken into account for dose estimation due to its short half-life (55.6 s) thoron has an inhomogeneous spatial distribution [8].

The dose conversion factors reported by ICRP 2017 [9] have been used to estimate the annual effective doses. In this estimation, the annual effective doses $\left[\mathrm{mSv} \cdot \mathrm{y}^{-1}\right]$ for radon $\left(D_{\mathrm{Rn}}\right)$ and thoron $\left(D_{\mathrm{Tn}}\right)$ were calculated using the following formulas:

$$
\begin{aligned}
D_{\mathrm{Rn}} & =C_{\mathrm{Rn}} \cdot F \cdot \mathrm{DCF}_{\mathrm{RnP}} \cdot \mathrm{OF} \\
D_{\mathrm{Tn}} & =\mathrm{EETC} \cdot \mathrm{DCF}_{\mathrm{TnP}} \cdot \mathrm{OF}
\end{aligned}
$$

where $C_{\mathrm{Rn}}$ is the radon concentration $\left[\mathrm{Bq} \cdot \mathrm{m}^{-3}\right.$ ], $\mathrm{DCF}_{\mathrm{RnP}}\left(17 \times 10^{-6} \mathrm{mSv} \cdot\left(\mathrm{Bq} \cdot \mathrm{h} \cdot \mathrm{m}^{-3}\right)^{-1}\right)$ is the radon dose conversion factor, EETC is the equilibrium equivalent thoron concentration $\left[\mathrm{Bq} \cdot \mathrm{m}^{-3}\right], \mathrm{DCF}_{\mathrm{TnP}}$ $\left(1.07 \times 10^{-4} \mathrm{mSv} \cdot\left(\mathrm{Bq} \cdot \mathrm{h} \cdot \mathrm{m}^{-3}\right)^{-1}\right)$ is the thoron dose conversion factor, and OF (7000 h) is the occupancy factor (the exposures time that was adjusted to one year and expressed in hours). For the calculation of equilibrium equivalent radon concentration (EERC), the equilibrium factor of 0.4 was used.

\section{Results and discussion}

Radon, thoron, and thoron progeny concentrations

A total of 45 dwellings were selected for radon, thoron, and thoron progeny measurements. This study took place from November 2018 to October 2019. The radon, thoron, and thoron progeny concentrations in indoor were ranged from 42 to $490 \mathrm{~Bq} \cdot \mathrm{m}^{-3}$, 20 to $618 \mathrm{~Bq} \cdot \mathrm{m}^{-3}$, and 4 to $40 \mathrm{~Bq} \cdot \mathrm{m}^{-3}$, respectively. The radon, thoron, and thoron progeny concentrations in outdoor were ranged from 49 to $435 \mathrm{~Bq} \cdot \mathrm{m}^{-3}$, 23 to $457 \mathrm{~Bq} \cdot \mathrm{m}^{-3}$, and 4 to $37 \mathrm{~Bq} \cdot \mathrm{m}^{-3}$, respectively. Table 1 shows a summary of radon, thoron, and thoron progeny concentrations in indoor and outdoor. The concentrations in both indoor and outdoor areas of Takandeang were the same because Takandeang is a high background radiation area and most of the buildings in this area are made from wood and as such these buildings are well ventilated [10]. Therefore, the concentrations of radon, thoron, and thoron progeny were the same.

Frequency distributions of indoor radon, thoron, and thoron progeny concentrations are shown in Fig. 2. The radon, thoron, and thoron progeny concentrations were examined for normality using the Shapiro-Wilk test. These tests revealed that thoron

\begin{tabular}{|c|c|c|c|c|c|c|c|}
\hline \multirow{2}{*}{\multicolumn{2}{|c|}{ Statistical parameters }} & \multicolumn{6}{|c|}{ Activity concentrations $\left[\mathrm{Bq} \cdot \mathrm{m}^{-3}\right]$} \\
\hline & & \multicolumn{2}{|c|}{ Radon } & \multicolumn{2}{|c|}{ Thoron } & \multicolumn{2}{|c|}{ Thoron progeny } \\
\hline & & Indoor & Outdoor & Indoor & Outdoor & Indoor & Outdoor \\
\hline \multirow{4}{*}{$\begin{array}{l}\text { Whole } \\
\text { study } \\
\text { area }\end{array}$} & Range & $42-490$ & $49-435$ & $20-618$ & $23-457$ & $4-40$ & $4-37$ \\
\hline & $\mathrm{AM} \pm \mathrm{SD}$ & $221 \pm 30$ & $208 \pm 22$ & $152 \pm 67$ & $139 \pm 89$ & $13 \pm 4$ & $15 \pm 4$ \\
\hline & GM (GSD) & $219(1.1)$ & $207(1.1)$ & $141(1.7)$ & $121(7.7)$ & $13(1.0)$ & $15(1.0)$ \\
\hline & $\mathrm{N}$ & 45 & 18 & 45 & 18 & 45 & 18 \\
\hline
\end{tabular}
had neither a normal nor a log-normal distribution (W-statistic: 0.847 ) as shown in Fig. 2b. Furthermore, radon and thoron progeny follow log-normal distribution (W-statistic: 0.963 and 0.961, respectively) as displayed in Figs. 2a and 2c.

Table 1. Statistical parameters related to the distribution of radon, thoron, and thoron progeny

Notes: AM - arithmetic means, GM - geometric mean, GSD - geometric standard deviation, N - number of dwellings, SD - standard deviation. 

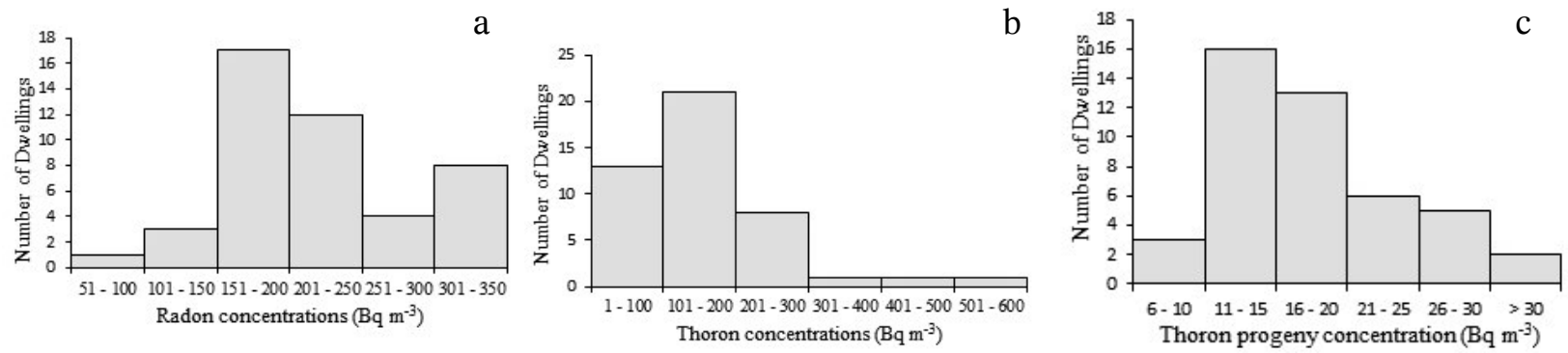

Fig. 2. Frequency distribution concentration for radon (a), thoron (b), and thoron progeny (c).
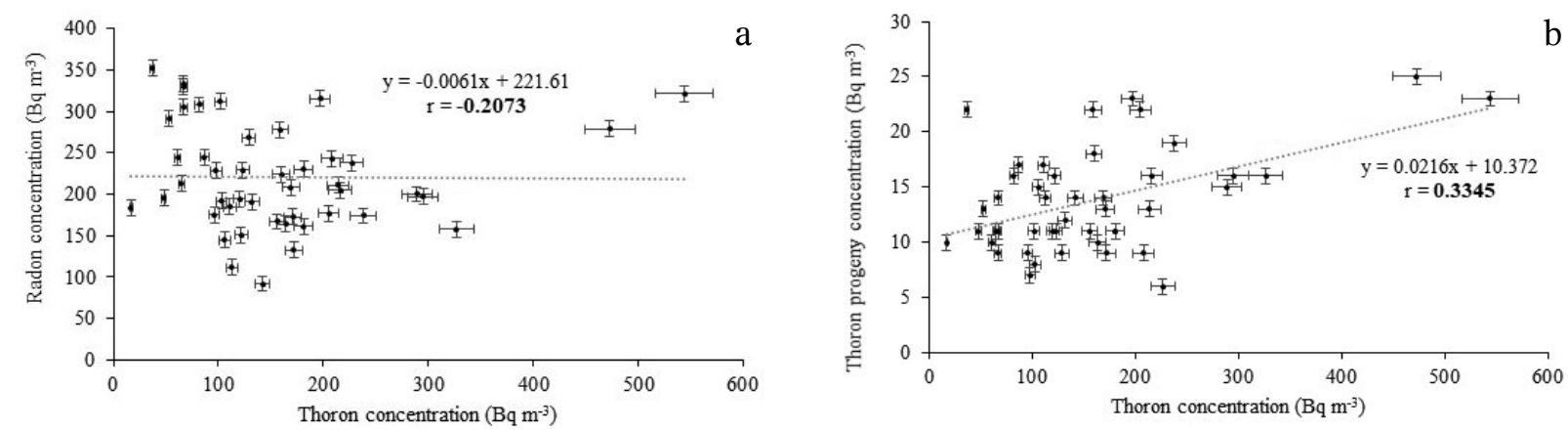

Fig. 3. Correlations plots between radon and thoron (a) and between thoron and thoron progeny (b).

The radon-thoron detectors were deployed at various distances from the walls of the investigated rooms. As thoron migrates only to a small distance from the source due to its short half-life $[6,8]$, the thoron concentrations observed in the present study may be affected by the detector locations. Consequently, the results of the thoron concentrations are just shown as references.

The Spearman's correlations analysis between indoor radon and thoron concentrations and between indoor thoron progeny and thoron concentrations was carried out (Figs. 3a and 3b). No correlation was found between radon and thoron concentrations $(r$ : -0.21 ) or between thoron and thoron progeny concentrations $(r: 0.33)$. Thus, indoor radon, thoron, and thoron progeny concentrations appear to be independent of each other, and this consequence is due to the significant difference between their half-lives. Thoron concentration varies considerably due to its short half-life, while the radon and thoron progeny concentrations tend to be distributed uniformly due to their relatively long half-life $[8,11]$. Furthermore, the observed radon concentration implies well-mixed indoor and outdoor air. These may mask a particular relationship between them. This also suggests that exposure to thoron cannot be predicted from exposure to radon and that the EETC has a large uncertainty when it is estimated from thoron concentration assuming a single thoron equilibrium factor.

\section{Influence of building materials on indoor concentration}

The materials used for building construction have an impact on the variability of radon and thoron concentrations [10]. Of the 45 houses selected for radon track and offspring measurement in the village of Takandeang, most of them are made of wood,

Table 2. Influence of building materials on indoor concentrations

\begin{tabular}{|c|c|c|c|c|}
\hline \multirow{2}{*}{ Building materials } & \multirow{2}{*}{ Statistic parameters } & \multicolumn{3}{|c|}{ Activity concentrations $\left[\mathrm{Bq} \cdot \mathrm{m}^{-3}\right]$} \\
\hline & & Radon & Thoron & Thoron progeny \\
\hline Unfired brick & $\begin{array}{c}\mathrm{AM} \pm \mathrm{SD} \\
\mathrm{GM}(\mathrm{GSD}) \\
\mathrm{N}\end{array}$ & $\begin{array}{c}274 \pm 77 \\
264(1.4) \\
6\end{array}$ & $\begin{array}{c}178 \pm 88 \\
122(1.5) \\
6\end{array}$ & $\begin{array}{c}17 \pm 6 \\
16(1.5) \\
6\end{array}$ \\
\hline Cement & $\begin{array}{c}\mathrm{AM} \pm \mathrm{SD} \\
\mathrm{GM}(\mathrm{GSD}) \\
\mathrm{N}\end{array}$ & $\begin{array}{c}242 \pm 59 \\
235(1.3) \\
10\end{array}$ & $\begin{array}{c}167 \pm 102 \\
137(2.1) \\
10\end{array}$ & $\begin{array}{c}13 \pm 5 \\
13(1.4) \\
10\end{array}$ \\
\hline Mix (brick + cement + wood) & $\begin{array}{c}\mathrm{AM} \pm \mathrm{SD} \\
\mathrm{GM}(\mathrm{GSD}) \\
\mathrm{N}\end{array}$ & $\begin{array}{c}225 \pm 52 \\
220(1.3) \\
11\end{array}$ & $\begin{array}{c}153 \pm 86 \\
132(1.8) \\
11\end{array}$ & $\begin{array}{c}14 \pm 5 \\
13(1.3) \\
11\end{array}$ \\
\hline Wood & $\begin{array}{c}\mathrm{AM} \pm \mathrm{SD} \\
\mathrm{GM}(\mathrm{GSD}) \\
\mathrm{N}\end{array}$ & $\begin{array}{c}189 \pm 52 \\
181(1.3) \\
18 \\
\end{array}$ & $\begin{array}{c}133 \pm 66 \\
116(1.7) \\
18 \\
\end{array}$ & $\begin{array}{c}14 \pm 5 \\
13(1.4) \\
18 \\
\end{array}$ \\
\hline
\end{tabular}

Notes: AM - arithmetic mean, GM - geometric mean, GSD - geometric standard deviation, N - number of dwellings, SD - standard deviation. 
Table 3. Statistical parameters of annual effective dose due to radon and thoron progeny

\begin{tabular}{lcccc}
\hline \multirow{2}{*}{\multicolumn{2}{c}{ Statistical parameters }} & \multicolumn{3}{c}{ Annual effective dose $\left[\mathrm{mSv} \cdot \mathrm{y}^{-1}\right]$} \\
\cline { 2 - 4 } & & Radon & Thoron progeny & Total \\
\hline \multirow{3}{*}{ Whole study } & Range & $3.4-12.1$ & $5.1-17.7$ & $9.8-28.6$ \\
area & AM \pm SD & $8.1 \pm 2.2$ & $10 \pm 3.2$ & $18.2 \pm 4.4$ \\
& GM (GSD) & $7.8(1.3)$ & $9.6(1.3)$ & $17.7(1.2)$ \\
\hline
\end{tabular}

Notes: AM - arithmetic mean, GM - geometric mean, GSD - geometric standard deviation, N - number of dwellings, $\mathrm{SD}$ - standard deviation.

some of them are made of unfired bricks, and some of them are made of mixed materials (cement + brick + wood). Table 2 shows a summary of the mean radon, thoron, and thoron progeny concentrations.

The highest radon, thoron, and thoron progeny concentrations were measured in unfired bricks house around $274 \pm 77 \mathrm{~Bq} \cdot \mathrm{m}^{-3}, 178 \pm 88 \mathrm{~Bq} \cdot \mathrm{m}^{-3}$, $17 \pm 6 \mathrm{~Bq} \cdot \mathrm{m}^{-3}$, respectively, having a geometric mean of $264 \mathrm{~Bq} \cdot \mathrm{m}^{-3}, 122 \mathrm{~Bq} \cdot \mathrm{m}^{-3}, 16 \mathrm{~Bq} \cdot \mathrm{m}^{-3}$, respectively, and the lowest one was recorded in a wood house.

\section{Estimation of annual effective doses}

The measured value of radon, thoron, and thoron progeny concentrations in 45 houses of Takandeang village was used for estimating the annual effective dose received by the population of the study area. The annual effective dose due to indoor radon was calculated by assuming a radon equilibrium factor of 0.4 . A range of 3.4-12.1 mSv $\cdot \mathrm{y}^{-1}$ was found with an arithmetic mean of $8.1 \pm 2.2 \mathrm{mSv} \cdot \mathrm{y}^{-1}$ and a geometric mean of $7.8 \mathrm{mSv} \cdot \mathrm{y}^{-1}$. The dose due to thoron progeny was calculated from the results of the thoron progeny deposition detectors. A range of 5.1-17.7 $\mathrm{mSv} \cdot \mathrm{y}^{-1}$ was found with an arithmetic mean of $10 \pm 3.2 \mathrm{mSv} \cdot \mathrm{y}^{-1}$ and a geometric mean of $9.6 \mathrm{mSv} \cdot \mathrm{y}^{-1}$. The results are summarized in Table 3 .

The frequency distributions of total annual effective dose due to radon and thoron progeny in 45 dwellings of the study area are represented in Fig. 4. It was calculated to be $9.8-28.6 \mathrm{mSv} \cdot \mathrm{y}^{-1}$, having an arithmetic mean of $18.2 \pm 4.4 \mathrm{mSv} \cdot \mathrm{y}^{-1}$ and a geometric mean of $17.7 \mathrm{mSv} \cdot \mathrm{y}^{-1}$, respectively.

\section{Conclusion}

Based on the result, the concentrations of radon, thoron, and thoron progeny in Takandeang village

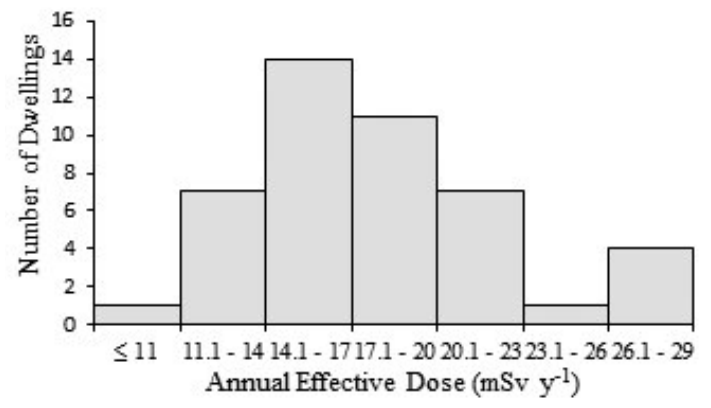

Fig. 4. Frequency distribution of annual effective dose due to radon and thoron progeny. are ranged from 42 to $490 \mathrm{~Bq} \cdot \mathrm{m}^{-3}, 20$ to $618 \mathrm{~Bq} \cdot \mathrm{m}^{-3}$, and 4 to $40 \mathrm{~Bq} \cdot \mathrm{m}^{-3}$, respectively. In addition, the outdoor concentrations are ranged from 49 to $435 \mathrm{~Bq} \cdot \mathrm{m}^{-3}, 23$ to $457 \mathrm{~Bq} \cdot \mathrm{m}^{-3}$, and 4 to $37 \mathrm{~Bq} \cdot \mathrm{m}^{-3}$, respectively. Therefore, the annual effective dose is estimated to be $9.8-28.6 \mathrm{mSv} \cdot \mathrm{y}^{-1}$. The Spearman's correlations analysis was carried out between indoor radon and thoron concentrations and between indoor thoron progeny and thoron concentrations (Fig. 3). No correlation was found between radon and thoron concentrations or between thoron and thoron progeny concentrations. Based on this result, we suggest that exposure to thoron cannot be predicted from exposure to radon, and the EETC has a large uncertainty when it is estimated from thoron concentration assuming a single thoron equilibrium factor.

Acknowledgment. The authors would like to express their thanks to health safety environment staff at the Center for Nuclear Minerals Technology - National Nuclear Energy Agency of Indonesia for their help in carrying out the measurement in Takandeang village, Mamuju, Indonesia. Also one of the authors (Miki Arian Saputra) is thankful to RISET PRO (Indonesian Government Scholarship) that gave financial support to continue his master course at Hirosaki University for two years and partially the Japan Society for Promotion of Science KAKENHI Grant no. 18KK0261 for partial support.

\section{References}

1. Katherem, R. L. (1998). NORM sources and their origins. Appl. Radiat. Isot., 49, 149-168. DOI: 10.1016/ s0969-8043(97)00237-6.

2. Klement, A. W. (1982). Natural sources of environmental radiation. Florida: CRC Press.

3. Syaeful, H., Sukadana, I. G., \& Sumaryanto, A. (2014). Radiometric mapping for naturally occurring radioactive materials (NORM) assessment in Mamuju, West Sulawesi. Atom Indonesia, 40(1), 33-39. DOI: 10.17146/aij.2014.263.

4. Omori, Y., Janik, M., Sorimachi, A., Ishikawa, T., \& Tokonami, S. (2012). Effects of air exchange property of passive-type radon-thoron discriminative detectors on performance of radon and thoron measurements. Radiat. Prot. Dosim., 152(1/3), 140-145. DOI: $10.1093 / \mathrm{rpd} / \mathrm{ncs} 210$.

5. Zhuo, W., \& Iida, T. (2000). Estimation of thoron progeny in dwellings with their deposition rate 
measurements. J. Health Phys., 35, 365-370. DOI: 10.5453/jhps.35.365.

6. Hosoda, M., Kudo, H., Iwaoka, K., Yamada, R., Suzuki, T., Tamakuma, Y., \& Tokonami, S. (2017). Characteristic of thoron $\left({ }^{220} \mathrm{Rn}\right)$ in environment. Appl. Radiat. Isot., 120, 7-10. DOI: 10.1016/j. apradiso.2016.11.014.

7. International Organization for Standardization. (2014). Measurement of radioactivity in the environment-Air-Radon 220: Integrated measurement methods for the determination of the average activity concentration using passive solid-state nuclear track detectors. ISO 16641:2014(E). Switzerland.

8. Ngoa Engola L., Ndjana Nkoulou, J. E., Hosoda, M., Bongue, D., Saïdou, , Akata, N., Koukong Heya, R., Kwato Njock, M. G., \& Tokonami, S. (2018). Air absorbed dose rate measurements and external dose assessment by car-borne survey in the gold mining areas of Betare-Oya, Eastern-Cameroon. J. Health Phys., 53(1), 200-209. DOI: 10.5453/jhps.53.5.

9. International Commission on Radiological Protection (2017). Occupational intakes of radionuclides: Part 3. (ICRP Publication 137). Ann. ICRP, 46(3/4).

10. Suzuki, G., Yamaguchi, I., Ogata, H., Sugiyama, H., Yonehara, H., Kasagi, F., \& Kimura, S. (2010). A nation-wide survey on indoor radon from 2007 to 2010 in Japan. 2010. J. Radiat. Res., 51(6), 683-689. DOI: 10.1269/jrr.10083.

11. Yamasaki, T., Guo, Q., \& Iida, T. (1995). Distributions of thoron progeny concentrations in dwellings. Radiat. Prot. Dosim., 59(2), 135-140. DOI: 10.1093/ oxfordjournals.rpd. a082644. 